\title{
Aktivitas Kuersetin sebagai Antihipertensi secara in silico
}

\section{Quercetin Activity as An Antihypertensive by in silico}

\author{
Dewa Ayu Pramesti Utari ${ }^{1 \bullet}$, Ni Putu Ruscita Anggreni ${ }^{1}$, Putu Rika Jesika Putri ${ }^{1}$, Ni Putu Linda Laksmiani ${ }^{1}$ \\ ${ }^{1}$ Program Studi Farmasi, Fakultas Matematika dan Ilmu Pengetahuan Alam, Universitas Udayana, Denpasar, Bali
}

\begin{abstract}
Abstrak: Hipertensi merupakan salah satu penyakit tidak menular yang memiliki prevalensi tinggi. Hipertensi disebabkan oleh terbentuknya Angiotensin II dari proses konversi dekapeptida inaktif Angiotensin I oleh angiotensin converting enzyme (ACE) yang akan menyebabkan penyempitan pembuluh darah. Selain itu, hipertensi juga dikaitkan dengan meningkatnya pembentukan reactive oxygen species (ROS). Pengembangan senyawa obat sebagai antihipertensi diperlukan untuk meningkatkan keberhasilan terapi yang belum adekuat. Sebagai salah satu senyawa bahan alam, kuersetin dipilih karena memiliki aktivitas sebagai $A C E$ inhibitor yang diketahui dengan melakukan uji in silico terhadap induksi ACE. Analisis data dilakukan dengan melihat energi ikatan yang dihasilkan dan ikatan yang terbentuk antara senyawa dengan residu asam amino pada protein. Hasil penelitian ini menunjukkan bahwa senyawa kuersetin berpotensi mengatasi hipertensi. Validasi metode menunjukkan konformasi 7 memiliki nilai RMSD yaitu $2,86 \AA$ dan energi ikatan antara protein target (ACE) dengan native ligan-nya yaitu $-4.66 \mathrm{kkal} / \mathrm{mol}$. Sedangkan nilai energi ikatan yang diperoleh antara senyawa uji kuersetin dan protein target yaitu $-6,32$ $\mathrm{kkal} / \mathrm{mol}$ dimana ikatan hidrogen yang terbentuk menghasilkan residu asam amino ALA356, HIS383, ALA356, TYR523, dan GLU411 berturut-turut melalui gugus O-H, HE2-O, HN-O, HH-O, dan OE1-H. Nilai energi ikatan yang didapat menunjukkan bahwa senyawa uji kuersetin memiliki aktivitas farmakologi sebagai sebagai $A C E$ inhibitor karena energi ikatannya lebih negatif dibandingkan dengan native ligand protein target yaitu lisinopril. Hal ini menunjukkan bahwa kuersetin dapat membentuk ikatan yang lebih stabil dibandingkan dengan lisinopril. Sehingga kuersetin berpotensi dalam pengembangan terapi hipertensi yang berperan sebagai ACE inhibitor.
\end{abstract}

Kata Kunci: ACE inhibitor, hipertensi, in silico, kuersetin.

\begin{abstract}
Hypertension is a non-communicable disease that has a high prevalence. Hypertension is caused by the formation of Angiotensin II from the conversion of an inactive decapeptide Angiotensin I by ACE which causes constriction of blood vessels. Hypertension is also associated with increased formation of reactive oxygen species (ROS) in blood vessels. The development of medicinal compounds as antihypertensives is needed to increase the success of inadequate therapy. As one of the natural compounds, quercetin has activity as an ACE inhibitor that can be determined by conducting an in silico test on ACE induction. Data analysis was carried out by looking at the resulting bond energy and the bonds formed between the compounds and the amino acid residues in the protein. The results of this research show that quercetin compounds are potential to treat hypertension. The validation showed that the conformation 7 had an RMSD value of $2.86 \AA$ and the bond energy between the target protein (ACE) and its native ligand was $-4.66 \mathrm{kcal} / \mathrm{mol}$. Meanwhile, the bond energy score between the quercetin and target protein test compounds is $-6.32 \mathrm{kcal} / \mathrm{mol}$ where the hydrogen bonds formed produce the amino acid residues ALA356, HIS383, ALA356, TYR523, and GLU411 respectively through $\mathrm{OH}, \mathrm{HE2}-\mathrm{O}, \mathrm{HN}-\mathrm{O}, \mathrm{HH}-\mathrm{O}$, and $\mathrm{OE} 1-\mathrm{H}$. The bond energy score shows that the quercetin test compound has pharmacological activity as an ACE inhibitor because the bond energy is more negative than the native ligand target protein, namely lisinopril. This shows that quercetin can form a stable bond than lisinopril. So that quercetin has the potential in the development of hypertension treatment, which acts as an ACE inhibitor.

Keywords: ACE inhibitor, hypertension, in silico, quercetin.
\end{abstract}

\section{PENDAHULUAN}

Hipertensi atau tekanan darah tinggi tergolong sebagai salah satu penyakit tidak menular yang dikenal menjadi masalah kesehatan global akibat prevalensinya yang tinggi. Prevalensi hipertensi di Indonesia secara nasional mencapai 25,8\%. Menurut Kementrian Kesehatan Republik Indonesia tahun 2014, apabila populasi penduduk di

•email korespondensi: dewaayu.pramesti17@gmail.com 
Indonesia sebesar 252.124.458 jiwa maka setidaknya terdapat 65.048.110 jiwa mengalami hipertensi. Bahkan, telah dinyatakan bahwa terdapat 13 provinsi yang persentasenya melebihi persentase secara nasional (Kemenkes RI, 2014). Suatu kondisi yang mengejutkan dimana pada tahun 2025 kasus hipertensi diperkirakan meningkat menjadi 29\% dari total penduduk dunia (WHO, 2011).

Penyebab hipertensi salah satunya yaitu angiotensin converting enzyme (ACE). ACE meningkatkan tekanan darah melalui proses konversi dekapeptida inaktif Angiotensin I menjadi bentuk aktifnya (Angiotensin II). Terbentuknya Angiotensin II akan menyebabkan terjadinya penyempitan pembuluh darah yang memicu terjadinya hipertensi (Zeng et al. 2013). Tekanan darah tinggi juga dikaitkan dengan peningkatan pembentukan reactive oxygen species (ROS) dalam pembuluh darah dan organ target seperti otak dan ginjal. Keberadaan ROS akan meningkatkan disfungsi vaskular dengan menyebabkan peradangan sehingga terbentuk mekanisme umpan balik positif yang menyebabkan terjadinya hipertensi (Fukai \& Fukai, 2011). Sebagai salah satu penyakit kronis, hipertensi juga dapat menjadi faktor resiko penyebab penyakit lainnya (AHA, 2014).

Penyakit hipertensi yang diderita oleh masyarakat Indonesia 90\% adalah hipertensi primer/hipertensi essensial, yaitu golongan hipertensi yang tidak diketahui penyebabnya. Namun kemampuan deteksi, dan pemilihan terapi, keberhasilan implementasi pengobatan hipertensi belum adekuat (Kemenkes RI, 2013). Salah satu senyawa obat yang telah diuji menghasilkan efek ACE inhibitor yaitu lisinopril yang merupakan senyawa sintesis. Adanya efek samping yang ditimbulkan dari pengobatan hipertensi tersebut mendorong adanya pengembangan senyawa bahan alam yang dapat dengan selektif terhadap protein target yang ditentukan (ACE) serta dapat meminimalkan kemungkinan timbulnya efek samping yang merugikan.

Salah satu senyawa bahan alam yang telah banyak mendapat perhatian sebagai salah satu alternatif pengembangan terapi hipertensi adalah kuersetin (Gambar 1). Kuersetin merupakan zat aktif dari golongan flavonoid yang berperan sebagai antioksidan. Keberadaan kuersetin dalam bahan alam cukup tinggi dimana konsentrasi kuersetin dalam daun kelor dapat mencapai 384,61 mg/100 g (Bhagawan et al., 2017). Berdasarkan aktivitasnya, kuersetin merupakan antioksidan karena memiliki komponen fenolik yang sangat reaktif menstabilkan senyawa-senyawa radial melalui reaksi hidrogenasi maupun pembentukan kompleks (Ikawati dkk., 2008). Kuersetin diketahui memiliki aktivitas farmakologi menurunkan tekanan darah dengan pendekatan mekanisme inhibisi terhadap enzim ACE (Larson et al. 2012).

Aktivitas kuersetin untuk terapi hipertensi dengan pembanding berupa enalapril, secara secara in silico telah diteliti dalam penelitian sebelumnya (Muhammad \& Fatima, 2015). Dengan demikian penelitian ini dilakukan dalam rangka pengembangan senyawa bahan alam yaitu kuersetin dengan cara mengetahui bagaimana mekanisme kuersetin sebagai ACE inhibitor secara secara in silico melalui molecular docking menggunakan standar lisinopril.

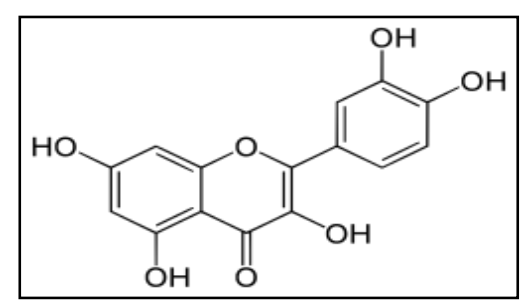

Gambar 1. Struktur Kimia Kuersetin (Daud dkk., 2011).

\section{METODE PENELITIAN}

Alat dan Bahan. Bahan yang digunakan yaitu struktur tiga dimensi dari kuersetin dan lisinopril yang dibuat dan dipreparasi pada program Hyperchem 8. Sampel struktur protein target berupa enzim yaitu ACE (PDB ID: 1086), yang diunduh dari http://www.rcsb.org. Peralatan yang digunakan dalam penelitian ini diantaranya yaitu: seperangkat komputer dengan spesifikasi Windows 864 bit dengan program Hyperchem 8 untuk preparasi dan optimasi senyawa uji kuersetin, Chimera 1.11 untuk preparasi protein target, dan Aplikasi AutoDock Tools 1.5.6. dilengkapi program Autodock 4 dan Autogrid 4 untuk molecular docking. 


\section{Prosedur Penelitian}

\section{a. Optimasi Senyawa Kuersetin}

Struktur 3 dimensi senyawa kuersetin dibuat dan dioptimasi dengan menggunakan program Hyperchem 8 lengkap dengan atom hidrogennya. Optimasi struktur 3 dimensi dari senyawa kuersetin dilakukan dengan menggunakan metode komputasi semi-empiris AM1 dan dilakukan kalkulasi melalui single point dan optimasi geometri.

\section{b. Preparasi Protein Target}

Preparasi protein diawali dengan memilih struktur protein target berupa ACE yang berada dalam bentuk aktifnya yaitu berikatan dengan native ligand berupa lisinopril (LPR) dengan PDB ID: 1086. Tahap pertama preparasi protein adalah penghilangan molekul air $\left(\mathrm{H}_{2} \mathrm{O}\right)$ pada protein target. Kemudian native ligand pada protein target tersebut dihilangkan dengan program Chimera 1.11 yang bertujuan untuk menyediakan ruang (pocket/cavity), sehingga koordinat pocket dan binding site center sebagai bahan docking dapat diketahui. Native ligan yang telah terpisah tersebut digunakan untuk validasi metode.

\section{c. Validasi Metode Molecular Docking}

Validasi dilakukan dengan redocking yaitu mendocking-kan kembali native ligand dengan protein target yang sebelumnya sudah dihilangkan native ligand-nya dengan aplikasi Auto Dock Tools 1.5.6 Parameter validasi metode molecular docking adalah nilai RMSD (Root Mean Square Distances) dari hasil docking dimana metode dinyatakan valid hanya saat nilai RMSD $\leq 3,0 \AA$ (Susanti dkk., 2018). Setelah metode yang digunakan valid, dilanjutkan dengan docking senyawa uji pada protein target.

\section{d. Docking Senyawa Kuersetin pada ACE}

Senyawa uji kuersetin yang sudah teroptimasi selanjutnya di-docking-kan pada protein target (ACE) yang sudah dipreparasi (dihilangkan native ligandnya) dengan menggunakan metode yang sudah tervalidasi. Docking dilakukan dengan menggunakan program Aplikasi AutoDock Tools 1.5.6. dilengkapi program Autodock 4 dan Autogrid 4. Hasil yang diperoleh dari proses docking kuersetin pada protein target ini adalah nilai energi ikatan dan jenis ikatan hidrogen yang terbentuk, kemudian dilakukan analisis terhadap hasil yang diperoleh.

\section{e. Analisis Data}

Analisis data yang dilakukan pada penelitian ini yaitu dengan metode deskriptif. Hasil molecular docking diantaranya berupa energi ikatan dan jenis ikatan hidrogen yang terbentuk antara senyawa dengan protein target. Jenis ikatan hidrogen yang terbentuk antara kuersetin dengan protein target digunakan untuk analisis mekanisme model interaksi yang terbentuk antara senyawa uji kuersetin dengan residu asam amino dari protein target. Sedangkan energi ikatan yang diperoleh digunakan untuk analisis afinitas dari kuersetin terhadap protein target ACE. Hasil energi ikatan yang negatif menunjukkan bahwa senyawa memiliki afinitas terhadap protein target sedangkan apabila bernilai positif maka senyawa uji tidak memiliki afinitas terhadap protein target ataupun memiliki afinitas yang sangat lemah. Semakin rendah nilai energi ikatan, maka ikatannya semakin kuat dan stabil. Hasil energi ikatan dari kuersetin dengan protein target yang diperoleh dibandingkan dengan energi ikatan dari protein target dengan native ligand untuk mengetahui potensi kuersetin sebagai ACE inhibitor.

\section{HASIL DAN PEMBAHASAN}

Optimasi dilakukan dengan menggunakan softwarfe HyperCham 8 untuk mendapatkan struktur yang stabil dari senyawa uji yaitu kuersetin dan lisinopril dalam bentuk tiga dimensi. Proses optimasi dilakukan berdasarkan metode mekanika kuantum yaitu metode semi empiris berupa AM1. Metode AMI cocok diterapkan untuk senyawa organik seperti kuersetin dan lisinopril karena memiliki kemampuan memperkirakan gugus $\mathrm{H}$ lebih baik dibandingkan dengan metode lainnya (Ramachandran et al., 2008). Selain itu, metode AMI memiliki tingkat akurasi yang tinggi dimana nilai error 5\% menandakan hasil optimasi akan semakin sama dengan data eksperimental (Wright et al., 2013).

Preparasi struktur tiga dimensi dari protein target dilakukan dengan memilih struktur protein dalam bentuk aktif yaitu masih berikatan dengan ligannya. Protein target dalam hal ini berupa 
angiotensin converting enzyme (ACE). Validasi metode dilakukan untuk menentukan bahwa nilai dari parameter yang digunakan memenuhi persyaratan dalam penggunaanya, sehingga hasil analisis berdasarkan metode tersebut dapat diterima (Harmita, 2004). Validasi metode dilakukan dengan penambahan atom hidrogen pada protein target tanpa native ligand-nya. Struktur native ligand diatur dalam kondisi yang fleksibel sedangkan protein diatur dalam kondisi yang rigid. Ukuran native ligand dan senyawa uji disesuaikan dengan ukuran grid box yang koordinatnya (dimensi $x, y$ dan z) telah diatur meliputi pengaturan grid center dan grid size. Dengan demikian native ligand hanya dapat berinteraksi dengan protein targset pada binding site yang telah ditetapkan.

Hasil validasi lisinopril sebagai ACE inhibitor ditunjukkan pada Tabel 1. Dari hasil tersebut dipilih konformasi 7 karena memiliki nilai RMSD kurang dari $3 \AA$ yaitu 2,86 A dengan nilai energi ikatan $-4,66$ kkal/mol. Sedangkan hasil validasi berupa visualisasi interaksi dapat dilihat pada Gambar 2. berupa senyawa kompleks yang terbentuk dari protein (ACE) dan native ligand-nya. Adapun ikatan yang dihasilkan berupa ikatan hidrogen pada residu asam amino GLY2000 melalui gugus HN3 pada protein dan 04 pada native ligand-nya.

Tabel 1. Hasil Validasi Metode Moleckular Docking ACE dengan Native Ligandnya (Lisinopril)

\begin{tabular}{ccccc}
\hline $\begin{array}{c}\text { Kon- } \\
\text { formasi }\end{array}$ & RMSD & $\begin{array}{c}\text { Energi } \\
\text { lkatan }\end{array}$ & $\begin{array}{c}\text { Residu } \\
\text { Asam } \\
\text { Amino }\end{array}$ & Gugus \\
\hline 7 & 2.86 & -4.66 & $\begin{array}{c}\text { GLY } \\
2000\end{array}$ & HN3-O4 \\
\hline
\end{tabular}

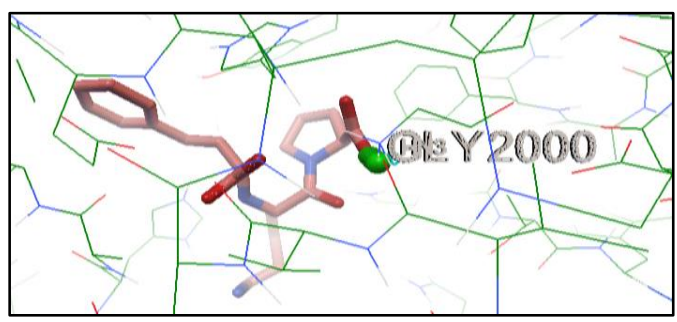

Gambar 2. Visualisasi ACE dengan Native Ligandnya (Lisinopril)
Proses docking dilakukan pada aplikasi dan koordinat grid box (tempat interaksi) yang serupa pada saat validasi metode. Hal ini dikarenakan bahwa metode yang digunakan pada kondisi tersebut telah tervalidasi dan dapat menjamin kebenaran proses docking. Nilai energi ikatan yang diperoleh dari hasil docking kuersetin dengan ACE ditunjukkan pada Tabel 2. Energi ikatan yang diperoleh dari ikatan senyawa kuersetin dan protein (ACE) yaitu -6,32 kkal/mol dimana nilai energi ikatan tersebut menyatakan kekuatan ikatan. Semakin rendahnya energi ikatan menandakan bahwa semakin kuat ikatan yang terbentuk antara senyawa uji dengan protein target (Susanti et al., 2018). Visualisasi hasil docking dari kuersetin dapat dilihat pada Gambar 3. Senyawa kompleks terbentuk dari ikatan hidrogen antara kuersetin (senyawa uji) dan ACE (protein target). Ikatan yang terbentuk menghasilkan residu asam amino ALA356, HIS383, ALA356, TYR523, dan GLU411 berturut-turut melalui gugus $\mathrm{O}-\mathrm{H}, \mathrm{HE} 2-\mathrm{O}, \mathrm{HN}-\mathrm{O}, \mathrm{HH}-\mathrm{O}$, dan $\mathrm{OE} 1-\mathrm{H}$.

Tabel 2. Hasil Docking Kuersetin Pada ACE

\begin{tabular}{cccc}
\hline Konformasi & $\begin{array}{c}\text { Energi } \\
\text { Ikatan }\end{array}$ & $\begin{array}{c}\text { Residu } \\
\text { Asam Amino }\end{array}$ & Gugus \\
\hline 4 & -6.32 & ALA356 & O-H \\
& & HIS383 & HE2-O \\
& & ALA356 & HN-O \\
& & TYR523 & HH-O \\
& & GLU411 & OE1-H \\
\hline
\end{tabular}

Berdasarkan data energi ikatan yang diperoleh diketahui bahwa senyawa kuersetin berpotensi memiliki aktivitas farmakologi sebagai antihipertensi karena energi ikatannya lebih negatif dibandingkan dengan native ligand protein target (lisinopril). Hal ini sekaligus menunjukkan bahwa kuersetin memiliki kemampuan untuk membentuk ikatan yang lebih stabil dibandingkan dengan senyawa standarnya (lisinopril) sehingga mampu berperan sebagai $A C E$ inhibitor. Potensi kuersetin sebagai ACE inhibitor juga dibuktikan dalam penelitian Muhammad and Nighat (2015) yaitu ikatan kuersetin dengan protein target lebih stabil dibandingkan dengan ikatan protein target dengan senyawa standarnya. 


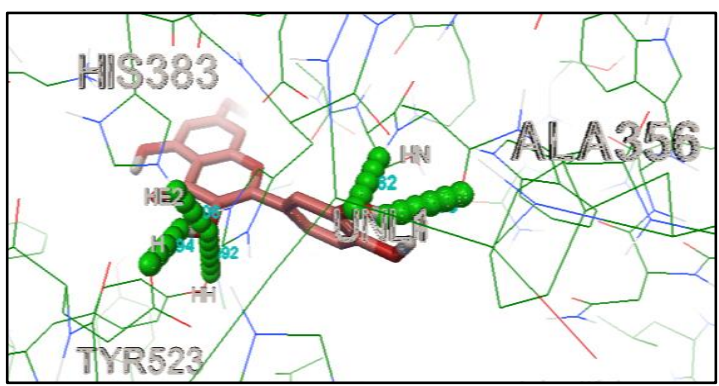

Gambar 3. Visualisasi Hasil Docking Kuersetin pada ACE

\section{SIMPULAN}

Senyawa kuersetin memiliki afinitas terhadap protein target yaitu angiotensin converting enzyme ( $\mathrm{ACE}$ ) yang ditunjukkan dengan hasil energi ikatan $-6.32 \mathrm{kkal} / \mathrm{mol}$. Hal tersebut menunjukkan bahwa kuersetin berpotensi sebagai anti-hipertensi dengan mekanisme menghambat kerja enzim ( $A C E$ inhibitor).

\section{UCAPAN TERIMA KASIH}

Penulis mengucapkan terimakasih kepada seluruh pihak yang terlibat dan membantu kelancaran jalannya penelitian ini.

\section{DAFTAR PUSTAKA}

AHA (American Heart Association). (2014). Heart Disease and Stroke Statistics. AHA Statistical Update.

Bhagawan, W. S., Atmaja, R. R. D., \& Atiqah. S. N. (2017). Optimization and Quercetin Release Test of Moringa Leaf Extract (Moringa oleifera) in Gel-Microemulsion Preparation. Journal of Islamic Pharmacy, 2(2), 34-42.

Daud, M.F., E.R. Sadiyah, dan E. Rismawati. (2011). Pengaruh Perbedaan Metode Ekstraksi Terhadap Aktivitas Antioksidan Ekstrak Etanol Daun Jambu Biji (Psidium guajava $\mathrm{L}$ ) Berdaging Buah Putih. Prosiding Seminar Nasional Penelitian dan PKM Sains, Teknologi, dan Kesehatan, 2(1), 55-62.
Fukai, T. \& Fukai, U. (2011). Superoxide Dismutases: Role in Redox Signaling, Vascular Function, and Diseases. Antioxid Redox Signal, 15(6), 1583-606.

Harmita. (2004). Petunjuk Pelaksanaan Validasi Metode dan Cara Perhitungannya. Majalah IImu Kefarmasian, 1(1), 117-135.

Ikawati, M., Wibowo, A. E., Navista, S. O. U., \& Adelina, R. (2008). Pemanfaatan Benalu Sebagai Agen Antikanker, International Seminar of Indonesia - Malaysia Update Benalu (Dendrophthoe pentandra (L.) Miq.) pada Mus musculus. Jurnal Exacta, 9(1), 1-8.

Kemenkes RI. (2013). Pedoman Teknis Penemuan dan Tatalaksana Hipertensi. Jakarta: Direktorat Pengendalian Penyakit Tidak Menular, Kementrian Kesehatan Republik Indonesia.

Kemenkes RI. (2014). Infodatin Hipertensi. Pusat Data dan Informasi Kementrian Kesehatan Republik Indonesia.

Larson, A. J., Symons D., \& Jalili T. (2012). Therapeutic Potential of Quercetin to Decrease Blood Pressure: Review of Efficacy and Mechanisms. American Society for Nutrition, 3(1), 39-46.

Muhammad, S. A. \& Fatima, N. (2015). In Silico Analysis and Molecular Docking Studies of Potential Angiostensin Converting Enzym Inhibitor Using Quercetin Glycosides. Pharmacognosy Magazine, 11(42), S123S126.

Ramachandran, K.I., Deepa, G., \& Namboori, K. (2008). Computational Chemistry and Molecular Modeling Principles and Applications. Springer. 
Susanti, N. M. P., Saputra, D. P. D., Hendrayati, P.L., Parahyangan, I. P. D. N., \& Swandari, I. A. D. G. (2018). Molecular Docking Sianidin dan Peonidin sebagai Antiinflamasi pada Aterosklerosis secara In Silico. Jurnal Farmasi Udayana, 7(1), 28-33.

WHO (World Health Organization). (2011). Hypertension Fact Sheet. Department of Sustainable Development and Healthy Environment.
Wright, P., Alex, A., \& Pullen, F. (2014). Predicting Collision-Induced Dissociation Spectra: Semi-Empirical Calculations as a Rapid and Effective Tool in Software-Aided Mass Spectral Interpretation. Rapid Commun. Mass Spectrom. 28(10), 1127-1143.

Zeng, Y., Wang, N., \& Qia, W. (2013). Production of Angiotensin I Converting Enzyme Inhibitory Peptides from Peanut Meal Fermented with Lactic Acid Bacteria and Facilitated with Protease. Advance Journal of Food Science and Technology, 5(9), 1198-1203. 